\title{
Helen Nield: 'There will always be a need for the library as a facilitator of dental knowledge'
}

\author{
Interview by Kate Quinlan
}

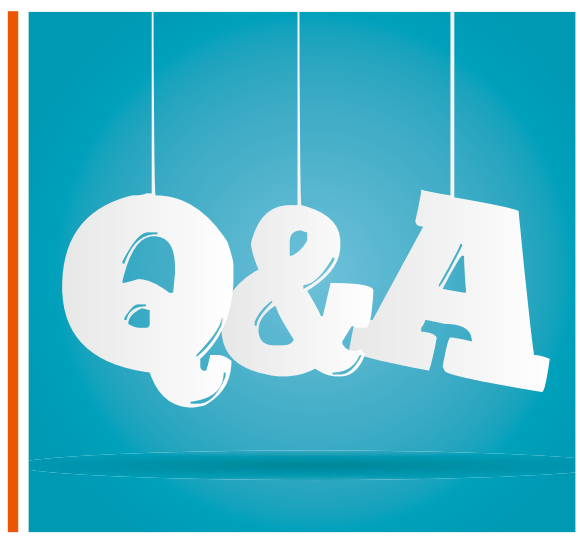

\section{T 0 ow does it feel to have been working at the BDA Library for 25 years?}

It feels like a very short time; it doesn't feel like 25 years. But when I look back at what it was like when I first started, and all the different staff that have come and gone, I realise it really is 25 years. But I'm not that old - I don't feel that old!

\section{What changes have you seen during the 25 years?}

Physically, the library has not changed all that much. When I first started, we didn't have carpet - we still had the cork tiles that were put in when the building was built in the 1960s - and where the BDA Museum is now, a few years after I started, that became the multimedia room and contained computers. Now, we have computers all over the place. The museum used to be where the boardroom is now on the ground floor.

The bookcases in the library are still the same as they were when the building was built.

Although there have been few physical changes to the library, there have of course been lots of changes to what we do. When I first started, the library had its own local area network which I had to back up every night - there was no BDA-wide computer network $\stackrel{\odot}{\ominus}$ and no IT department. Mostly, we dealt

\section{1 marks 25 years since Helen Nield began working at the BDA Library - known officially as the 'Robert and Lilian Lindsay Library'. In 2018, Helen} became Head of Library and Knowledge Services when Roger Farbey retired. Helen, who is from South East London, read Theology at New College, Oxford. In February 2020, just before the COVID-19 pandemic began, dentists, librarians and BDA staff gathered to celebrate the library's centenary.

with enquiries by phone and post, but now the majority of enquiries are done by email. We do still have photocopiers, but we use them more for scanning and emailing than printing articles now.

This year, we've bought a database called Dentistry and Oral Science Source (DOSS). It has over 250 full text dental journals on it, so BDA members can now access those online and don't have to request content from them.

We have nearly 600 e-books, which means that members have instantaneous access to books. This is obviously very useful during the pandemic when they can't get to the library and we can't get to the library to post books out.

We used to have a large, busy video library - now members rarely even borrow DVDs - and we are starting to provide a curated section on our library catalogue of existing YouTube videos related to dentistry. For example, we have added the Dr Ranj videos created by the British Society of Paediatric Dentistry.

So, electronic access is what has changed most. When I started, we didn't have a proper website or online library catalogues; members just had to phone up and ask us what we had or write to us. Members are a lot more connected to the library than they used to be.

\section{Why did you choose to study theology?}

Well, initially, I was going to study history because my history teacher was the only one that would coach people for the Oxford entrance exam, which is what I took. It was also because of my mum, who read history at university. I didn't have a huge interest in doing history, but that's why I did it.

I went to New College, Oxford. After the first year, I had learnt a bit more about what university involved and the different subjects, and I wasn't enjoying history. So, I switched to theology, which is a whole mixture of different disciplines.

I had to learn New Testament Greek, so I know some Greek and some Hebrew. I do like languages and have enjoyed learning French and German. Studying theology also involves literary criticism - mainly looking at the Bible - studying it and looking at the language behind it and the history of it; looking at the history of how religion developed. I have to say that my favourite paper during university was 'Ancient Near Eastern Myths and Religion', which included the amazing story of Gilgamesh.

I generally only read fiction, so I really enjoyed reading ancient myths. I loved Egyptology - I should have done archaeology, really. I think I would have enjoyed doing that. Because I switched 
1 topics, I had to do four years at Oxford instead of three, so I got to enjoy an extra year of university.

I started teacher training and only lasted a term; it wasn't for me. So then I applied for all sorts of things including a job as a station manager at a railway station, but eventually a careers advisor told me to try libraries.

So, I signed up with a library association agency, then Roger Farbey at the BDA Library interviewed me and gave me a temporary job for six months in 1993 while Damyanti was on maternity leave. Roger took a chance on me and I was very grateful to him.

After the maternity cover, I did a postgraduate diploma in information studies while working at the BMA library, then I came back to the BDA in 1996.

\section{You have been quoted as saying that the BDA Library is arguably the best dental library in the world. Why do you think it is?}

I think our dental library is unique because it was built up originally by a dentist and not a librarian - and so organised by somebody who really knew the subject.

We always put members first. Whatever they ask us, we try our best to supply it to them as much as we can, even when members are asking for things that aren't specifically dental. Also, the comprehensive nature of the collection. We have current clinical books and journals, but also a large historical collection. We have a very important rare books collection, which

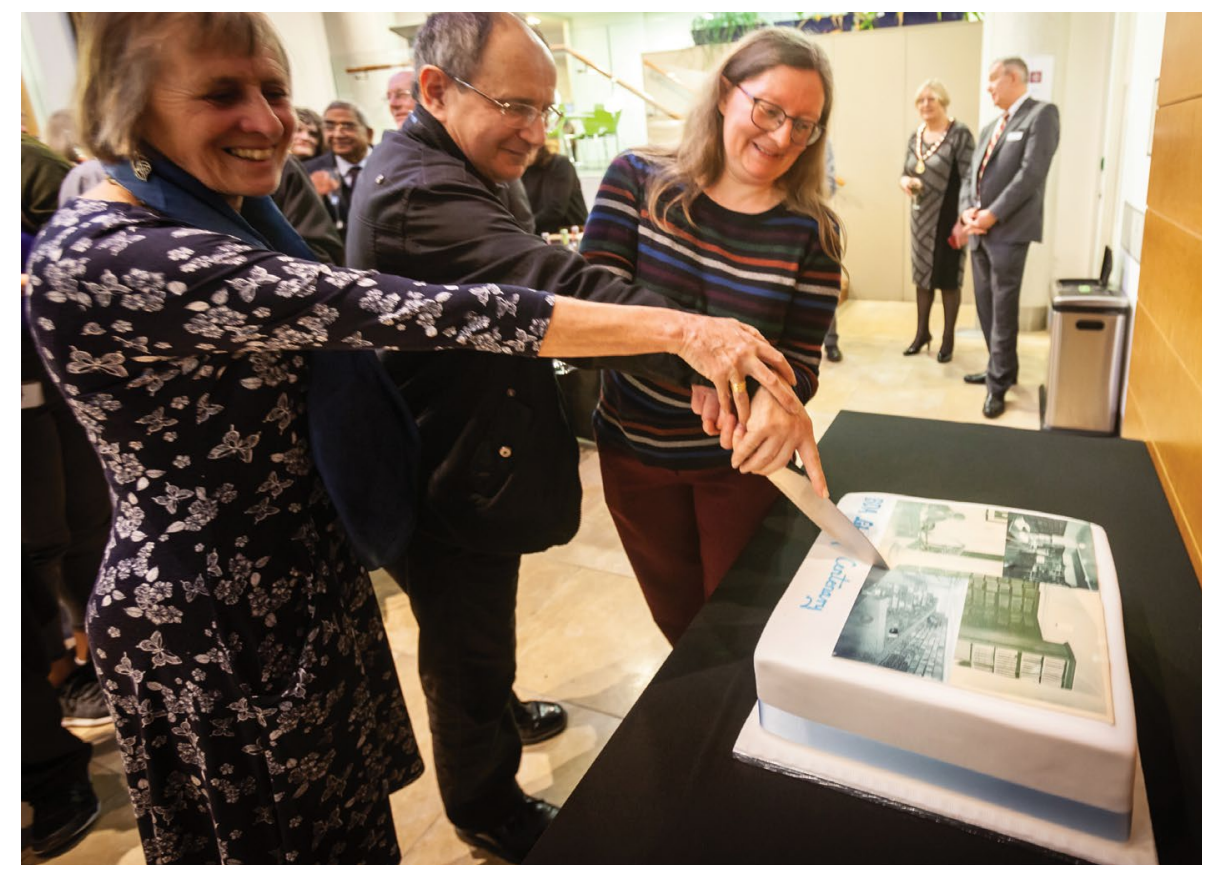

Helen Nield (right) with former Heads of the Library Roger Farbey and Margaret Clennett, cutting the cake at the BDA Library's centenary celebration, February 2020

and an archive of all kinds of dentistry.

We also have archives of all kinds of correspondence, including correspondence from dentists in the nineteenth century as they were setting up the professionalisation of dentistry, and we have a number of different letters, such as a letter from Florence Nightingale to her dentist.

There is also the breadth of knowledge that exists in the library staff. I've been there for 25 years this year and my colleague Damyanti for 27 years. My colleague Amy has been there about 15 years and Pete, the library manager, has only been there

\section{'Our dental library is unique because it was built up originally by a dentist and not a librarian'}

includes the first dental book in the English language, Charles Allen's The operator for the teeth, published in 1687. Our earliest book, Zene Artzney, was published in 1536 and is one of the very first dental books. Written in German, it's basically a collection of classical writings on the teeth.

We have a lot of important dentistry books from the eighteenth and nineteenth centuries; extensive electronic resources; three years but was at the Royal College of Nursing (RCN) for many years, so we have a depth of knowledge and we also work very closely with the museum. Rachel Bairsto has been the museum curator for a long time and she is surrounded by a number of volunteers who are mostly dentists, so there is a lot of knowledge that we can call upon when responding to members' requests and queries.

\section{Can you describe your typical working} day when the library is open?

There is never a typical day because you never know what's going to come in. What I miss about not being in the library is saying hello to Damyanti and Pete, then going up to sit in the office with Amy. I start the day going through emails and responding to enquiries, which could be anything.

You never know what literature searches you're going to be asked for. Just this week, I've had to do a search on theories of occlusion, another on how certain diets work with chemotherapy, and short implants combined with vertical bone augmentation in a posterior mandible. You have to focus your mind on the topic at hand and do a literature search.

We conduct journal searches using Medline and send members a list of references with abstracts so that they know what articles have been published on that topic.

Sometimes, we look at books to see if there's anything useful to them, and we scan and email articles to them. We can recommend books and we also have packages of articles on specific topics, which normally we would post out. They are more general than the journal search, but researchers do find them useful to help them to read up on particular topics.

Once a week, I tend to go through all the e-book platforms and see what new 
14 e-books are out and if there is anything worth buying. I advertise new e-books to see if anybody's interested in them before buying them for the library so that I'm not just buying in a vacuum.

Normally, Damyanti and Pete tend to do book loans. However, while we're in lockdown, I've been buying new books and getting them sent to me at home - so I've been doing book loans.

During lockdowns, people haven't been returning a lot of the books because they're unsure if the post is being received, so my colleague Amy has just now chased all the very, very late books and asked them to send them to me. That way, I can keep the system going. We didn't send any books out between March and August. People are still reserving books and wanting to wait for them because a lot of people prefer a hard copy book to an e-book, even now.

\section{How has your working day differed during the pandemic?}

Well, not commuting: I spend my whole day working in the kitchen on my laptop. In terms of what I do, it's not changed a lot, but what I can't do is access the physical library. If we're doing any historical enquiries, it is difficult to access everything.

We have a team meeting every month on the phone and we keep in contact by emailing every day, to try and keep the team together, and we work very closely with
Rachel from the museum as well because she's on her own. We try and make a larger team with her.

Between August and October 2020, Pete and I were going into the library once a week and it was like a ghost town really: one members that come in work locally. We have regulars that come in once or twice a week. They're reading up on the latest journals and like to have the physical journals to flick through, to broaden their knowledge and help with CPD, presumably.

\section{'What I do miss is the casual nature of seeing people and speaking to them'}

person from the facilities team and maybe someone from the finance team who would have to go in to do things physically with their machines. It felt strange, but it was good to get back and see that the library was still there.

What I do miss is the casual nature of seeing people and speaking to them; perhaps seeing someone from another team in the BDA foyer might spark something off - you might learn about something that is going on and it helps you to plan. I'm looking forward to getting back to that in the future.

\section{Why do people visit the BDA Library in the twenty-first century?}

Visitors have to be BDA members or bona fide researchers; we don't let members of the public come in off the street. The majority of

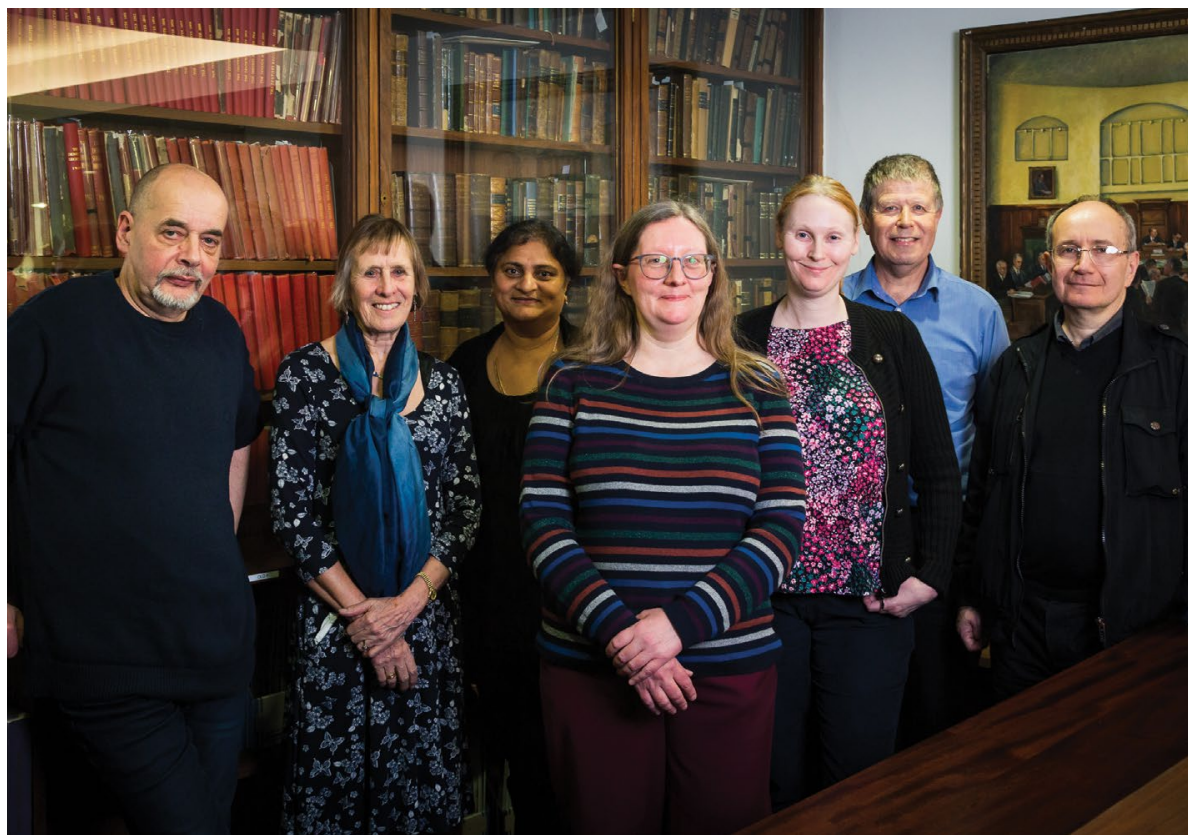

BDA Library staff past and present. Left to right: Pete Folly, Library Manager; former Head of Library Margaret Clennett; Damyanti Raghvani, Senior Library Officer; Helen Nield, Head of Library and Knowledge Services; Amy Grinnell, Library Officer; former Assistant Librarian Julian Roland; and former Head of Library Roger Farbey
There are also people that come in from slightly further away that like to browse through the books. They're generally GDPs. And then we have academic researchers that will come in to do a specific bit of research and make one-off visits. We also see visitors who are always researching, such as Professor Stanley Gelbier.

There are dentists that tend to use the BDA as a base. They come in and they'll check their emails and then they'll go away again.

We don't mind visitors having a cup of coffee in the library - we don't like them eating but we allow them to drink, with trepidation because somebody did spill a cup of hot chocolate over a journal once!

We also have visitors from universities who are doing postgraduate research that relates to dentistry, even though they might not be dentists themselves. We will give them permission to come in and use our archives and do research.

We sometimes have dentists from abroad who come and visit as well; they might want to see what the library is like and have a look round. We had somebody from Australia who was looking at Lilian Lindsay's notebooks.

Recently, we've had quite a lot of schoolchildren who are coming to the end of their time at school and are doing extended essay questions, and some choose dental topics. We email them a letter with a list of things that they might want to look at, then they'll come in and look through the collection.

In recent years, visitor numbers have gone down slightly because so much is now online, but I think the number of local dentists visiting is more or less the same as it was. I think they like to get away 
14 from their practice for a little bit, at lunchtime or inbetween patients.

\section{Is there a most borrowed book in the BDA Library?}

I wouldn't say there was a most borrowed book. We have just run a survey on what people think is the most influential dental book since 1920, having just celebrated our centenary. The winner of that survey, with $30 \%$ of the votes, was Scully's medical problems in dentistry.

[Editor's note: look out for the full results in a $B D J$ soon.]

\section{Do you know how many books there are in the library?}

There are about 29,500 books, not including our journals which take up the majority of our basement space. Older books might be moved down to the basement, or if we have ten copies of a book, we might move two down to the basement and put eight on our 'for sale' trolley. We have a little trolley by the door selling off extra copies, otherwise we'd run out of room! We very rarely completely get rid of a title, but we have got rid of a lot of computer-type books over the years as they have become out of date - manuals on WordPerfect, for example.

We have a number of locked cases in the basement for the really old books and locked glass cabinets in the main library where some of the nineteenth-century books are. Everything is accessible on request.

\section{Are you a great reader yourself? Do you have a favourite book?}

I read less now that I'm not commuting. I only read for a short time really in bed. I tend to read all sorts: a lot of nineteenth-century fiction, crime fiction and fantasy fiction.

My favourite book ever is Jane Eyre; I tend to read that periodically. I think that it is a very feminist novel, but the feminist aspects of it tend to get overlooked. One day, I will write a feminist critique of it.

\section{After 25 years of looking after dental books, do you feel knowledgeable about dentistry?}

I feel knowledgeable about the words. I wouldn't put me in front of the patient or anything! You could ask me to do a search on anything related to dentistry and I would feel confident in doing it.

\section{Do you have any upcoming plans or} events for the library, pandemic allowing?

We had our big centenary event in 2020. This year is 100 years since the Dentists Act of 1921, so there are plans to do something around that. Rachel in the museum is planning to do something and I expect we will join in, and I've been helping with the research for it already.

The main plan for this year is, of course, just to get back to normal, if we can.

\section{What do you like doing in your spare time?}

During lockdown, I've done a lot of knitting in front of the television. I knit clothes and toys. I crochet. I tend to have binges of trying different craft things, so I've tried macramé and I've tried lace making. It didn't last very long because you spend hours and hours on it and just have a tiny little thing to show for it.

My partner and I like to go out to local parks to watch the wildlife, especially the birds in spring. South Norwood country park has kestrels that nest there every year and we've regularly seen the young kestrels branching around the nest box - and one year we were lucky enough to see them fly out of the box for the first time which was magical.

One thing I'm really looking forward to when things get back to normal is playing Scrabble with my mum. I have brothers in London and Yorkshire and my parents are in Kent, but I haven't seen any of them since March, except when my parents came to stand on the doorstep on Christmas Day in their masks. We all Zoom once a month, so actually I've seen more of my brothers this year than I do normally. It has been nice - maybe it will carry on when things get back to normal.

\section{What else are you looking forward to when the pandemic restrictions are lifted?}

Getting back to the library and making it normal again to go into work and see people and chat to them. That's what I've missed really, bumping into people and saying hello.

When I was going into the library once a week during 2020, I was walking from Charing Cross to Wimpole Street to avoid using the tube and the bus and it's such a nice walk. I was going through the back streets to avoid the main road as well and you just soak up the history and the buildings. It would be nice to do that again and not worry about avoiding people.

\section{Do you think the BDA Library will still be around in 2120?}

Yes, there will always be a need for the library as a facilitator of dental knowledge for dentists and students as well as for a collection to place dentistry in its historical context. Librarians will still be needed in the future to facilitate, organise and research organic information.

Dentistry itself will no doubt have changed; I'm assuming it will be more preventative.

When it comes to books, people still like paper. I have to say that when I'm reading now, I use a Kindle, but for research it's still better to flick backwards and forwards in a paper book.

\section{I haven't been to a library for years. Do you still use a date stamp?}

Yes! For book loans. We used to date all the correspondence, but we hardly receive any through the post now. I've got old photos of staff in the library surrounded by piles and piles of post.

My team has been brilliant through the lockdown, weve all pulled together and adapted and carried the service on. More members have actually used the BDA Library this year than the year before, which is good. 